\title{
Article
}

\section{Biomarkers of sensitivity to potent and selective antitumor 2-(4-amino-3- methylphenyl)-5-fluorobenzothiazole (5F203) in ovarian cancer ${ }^{\dagger}$}

\section{MARIANA A. CALLERO ${ }^{1,2}$, GABRIELA A. LUZZANI ${ }^{1}$, DIANA O. DE DIOS ${ }^{3}$, TRACEY D. BRADSHAW ${ }^{4}$ AND ANDREA I. LOAIZA PEREZ ${ }^{1,2^{*}}$}

${ }^{1}$ National Scientific Council (CONICET), Argentina.

${ }^{2}$ Research Area, Institute of Oncology "Ángel H. Roffo”, University of Buenos Aires, Avenue San Martín 5481, C1417DTB, Ciudad de Buenos Aires, Argentina.

3 Gynecologic Oncology Department, Institute of Oncology "Ángel H. Roffo", University of Buenos Aires, Avenue San Martín 5481, C1417DTB, Ciudad de Buenos Aires, Argentina.

${ }^{4}$ Centre for Biomolecular Science, University of Nottingham, NG7 2RD, UK.

*Address correspondence to: Dr. Andrea I. Loaiza Perez. Research Area, Institute of Oncology “Ángel H. Roffo", University of Buenos Aires. Avenue San Martín 5481, C1417DTB, Ciudad de Buenos Aires, and Argentina. Tel: + 54-11-45047884; Fax: + 54-11-45802811. Email:loaizaa2012@gmail.com

Running title: "Markers of 5F203 activity in ovarian cancer"

Keywords:

- AhR

- CYP1A1

- ROS

- ovarian cancer

- 5 F203

Contract grant sponsor: Institute of Oncology "Ángel H. Roffo", University of Buenos Aires, Argentina.

${ }^{\dagger}$ This article has been accepted for publication and undergone full peer review but has not been through the copyediting, typesetting, pagination and proofreading process, which may lead to differences between this version and the Version of Record. Please cite this article as doi: [10.1002/jcb.24589]

Additional Supporting Information may be found in the online version of this article.

Received 7 March 2013; Revised 16 April 2013; Accepted 1 May 2013 Journal of Cellular Biochemistry (C) 2013 Wiley Periodicals, Inc. DOI 10.1002/jcb.24589 


\section{Abstract}

2-(4-amino-3-methylphenyl)-5-fluorobenzothiazole (5F203, NSC 703786) lysylamide belongs to a novel mechanistic class of antitumor agents. It elicits activity against ovarian, breast, kidney and colorectal cancer models. In sensitive breast cancer cells, 5F203 activates aryl hydrocarbon receptor (AhR) signaling. Herein, we evaluate the role of AhR in 5F203 activity in two ovarian cancer cell lines: IGROV-1 (sensitive to 5F203), SKOV-3 (resistant to this agent). In addition, cancer cells have been isolated from ascites fluid of ovarian cancer patients; sensitivity to 5F203 and concurrent AhR signal transduction has been examined in ascites-isolated ovarian cancer patients`cells.

5F203 induced enhanced CYP1A1 expression, AhR translocation and ROS formation in IGROV-1 cells and ascites-isolated ovarian cancer cells that were sensitive to 5F203. In IGROV-1 cells 5F203-induced ROS formation was accompanied by JNK, ERK and P38MAPK phosphorylation, DNA damage and cell cycle arrest prior to apoptosis. In contrast, 5F203 failed to induce CYP1A1 expression, AhR translocation or oxidative stress in 5F203-resistant SKOV-3 cells, or in ovarian cancer ascites cells inherently resistant to this agent.

We propose that AhR may represent a new molecular target in the treatment of ovarian tumors and 5F203 may exemplify a potential novel treatment. Furthermore, putative biomarkers of sensitivity to this agent have been identified. 


\section{Introduction}

Ovarian malignancies, the second cause of gynaecological cancer death in developed countries possess poor prognoses. Detected at advanced stages of disease (III and IV), the standard of care is cytoreductive surgery followed by platin- and taxane-based chemotherapy. Intrinsic- or acquired resistance to cytotoxic drugs result in significant risk of recurrence; therefore, the discovery of new molecular targets and more effective therapies remain vital (Romero and Bast, 2012). It has been proposed that high-grade advanced stage papillary serous ovarian adenocarcinoma ascites fluid is enriched for "metastasis initiating cells" which may represent a therapy-resistant population. Thus, ascites is considered a good model for disease study (Vathipadiekal et al., 2012).

Antitumor benzothiazoles including, 2-(4-amino-3-methylphenyl)-5-fluorobenzothiazole (5F203; NSC 703786; Fig. 1A), non-fluorinated parent compound DF203 (NSC 674495) and Phortress (NSC 710305), the lysyl amide prodrug of 5F203, are anticancer agents with activity in ovarian and breast cancer models in vitro and in vivo (Bradshaw et al., 2000; Fichtner et al., 2004). These compounds require metabolism by cytochrome P450 (CYP) enzymes (e.g. CYP1A1) for antitumor action. The aryl hydrocarbon receptor (AhR) is the main transcriptional regulator of CYP1A1 and we have previously demonstrated that DF203 and 5F203 induce activation of AhR signaling in sensitive breast cancer cells, causing nuclear translocation of AhR (Loaiza Perez et al., 2002; Bradshaw et al., 2008). Also, IGROV-1 human ovarian cancer cells, sensitive to 5F203 treatment, show induction of CYP1A1 expression by 5F203 and Phortress whereas SKOV-3 cells, resistant to these agents, express neither constitutive nor inducible CYP1A1 (Hose et al., 2003). Fine needle aspirates obtained from IGROV-1 human xenografts, treated ex vivo with 5F203 resulted in induction of CYP1A1 expression. This was not observed in 5F203-resistant tumors. It was proposed that induction of CYP1A1 mRNA in response to 5F203 treatment ex vivo may provide a possible biomarker for determination of drug-sensitive ovarian tumors in patients (Hose et al., 
2003). Compounds that activate AhR signaling and induce CYP expression frequently generate reactive oxygen species (ROS) in susceptible cells. Experimental and clinical evidence has emerged linking oxidative stress to pathologies including carcinogenesis (Ziech et al., 2011). However, oxidative stress is not always detrimental, and may, if induced in a selective manner, be of therapeutic benefit. Many chemotherapeutic agents induce oxidative stress integral to their antitumor mechanism (Tandon et al., 2005). High grade ovarian tumors generally present high ROS levels and respond better to treatment with antitumor agents that induce further ROS, such as paclitaxel (Mateescu et al., 2011). In addition, cJUN amino terminal kinase (JNK), ERK and P38MAPK sustained activation have key roles in cellular stress-induced apoptosis (Zuco et al., 2004).

Herein, we demonstrate that 5F203 induced enhanced CYP1A1 expression and AhR nuclear translocation in IGROV-1 cells and ascites-isolated ovarian cancer cells that were sensitive to 5F203. 5F203 possessed antiproliferative/pro-apoptotic activity evoking ROS formation, JNK, ERK and P38MAPK phosphorylation, DNA damage and cell cycle arrest prior to apoptosis. In contrast, 5F203 failed to induce CYP1A1 expression, AhR translocation or oxidative stress in 5F203-resistant SKOV-3 cells, or in ovarian cancer ascites cells inherently resistant to this agent.

Our studies demonstrate theranostic pharmacodynamic markers of 5F203 activity and provide additional insight into molecular targets of this novel anticancer agent, which may benefit ovarian cancer patients with limited therapeutic options.

\section{Materials and Methods}

\section{Cell lines}

Human ovarian cancer cell lines IGROV-1 and SKOV-3 were obtained from the American Type Culture Collection (ATCC, Manassas, VA, USA). Cells were cultured with 5\% $\mathrm{CO}_{2}$ in RPMI 1640 medium (Invitrogen, Carlsbad, CA, USA) supplemented with 10\% FBS (Invitrogen) and passaged 
weekly. Cells were resurrected at early passages from the nitrogen bank and discarded after 10 passages to ensure minimal phenotypic drift.

\section{Primary cultures}

Informed consent was obtained from women who had undergone surgery at Ángel H. Roffo Oncology Institute. Peritoneal fluids were obtained at the time of initial cytoreductive surgery. Cancer cells in ascites fluid were identified and verified by pathologists within the pathology department at Ángel H. Roffo Oncology Institute.

Fresh effusions drained from each patient were transferred to $50 \mathrm{ml}$ tubes. Cells were prepared according to Shepherd et al., 2006. Tumor cell samples were used at low passage $(<5)$, cultured with $5 \% \mathrm{CO}_{2}$ in $\mathrm{MCDB} / \mathrm{M} 199$ supplemented with $10 \% \mathrm{FBS}$ and passaged weekly.

\section{AhR Western blot}

Cells were seeded at $6 \times 10^{5}$ in T25 flasks $24 \mathrm{~h}$ before treatment with $1 \mu \mathrm{M} 5 \mathrm{~F} 203$ for $30 \mathrm{~min} 3 \mathrm{~h}, 6$ $\mathrm{h}$; $0.1 \%$ DMSO $6 \mathrm{~h}$ or $10 \mathrm{nM}$ 2,3,7,8-tetrachloro-dibenzo-p-dioxin (TCDD) $1 \mathrm{~h}$. Following treatment, cells were harvested, lysed and centrifuged using a commercial kit (NER-PER, Pierce, Rockford, IL, USA) to isolate cytosolic and nuclear fractions. Protein concentrations were determined using the Bradford assay. Fractions were analyzed by Western blot with rabbit $1^{\circ} \mathrm{Ab}$ against human AhR (sc-5579, Santa Cruz Biotechnology, CA, USA). Membranes were incubated with goat anti rabbit IgG-HRP $2^{\circ}$ Ab (Santa Cruz, sc- 2004) and visualized using enhanced chemiluminescence. Equal protein loading was confirmed by reprobing membranes with mouse anti-actin Ab (Sigma, A5441).

\section{Confocal laser scanning microscopy}

Cells were seeded into sterile petri dishes containing a single sterile coverslip in $10 \mathrm{ml}$ medium, and allowed to attach overnight $(\mathrm{o} / \mathrm{n})$. Medium containing 5F203 $(1 \mu \mathrm{M})$ was introduced and 
cultures incubated at $37^{\circ} \mathrm{C}$. After treatment, cells were fixed with $4 \%$ neutral buffered formalin and permeabilized with $0.1 \%$ Tween in PBS. Slides were blocked at $4^{\circ} \mathrm{C}$ for $1 \mathrm{~h}$ with $5 \%$ BSA in PBS and washed with PBS (3x) before incubation $(\mathrm{o} / \mathrm{n})$ with anti-AhR rabbit polyclonal $\mathrm{Ab}(\mathrm{sc}-5579$, Santa Cruz Biotechnology; 1:100 in PBS). Slides were washed 3x with PBS, before incubation with goat anti-mouse Alexa 488-conjugated $2^{\circ}$ Ab (Sigma; 1:100, 3 h). Following further PBS washes $(3 \mathrm{x})$, slides were incubated with 1:5000 propidium iodide (2 $\mathrm{mg} / \mathrm{ml}$; Sigma). Cells (on coverslips) were mounted onto glass slides using fluoromount (BDH Laboratory Supplies, Poole, UK) and stored at $4{ }^{\circ} \mathrm{C}$ in the dark. Specimens were examined using a Fluorescence Nikon C1 Confocal Microscope using a 40x PlanApo AN 0. 95 objective, images were processed and analyzed with Nikon C1-EZ package, version 2.20.

\section{Transient transfections}

Cells were plated in 24 well plates and after $24 \mathrm{~h}$ were transfected using lipofectamine 2000 (Invitrogen) with $0.5 \mu \mathrm{g}$ Renilla reniformis luciferase and $1.5 \mu \mathrm{g}$ pTX.Dir plasmid (two XRE sequences extending from nucleotides -1026 to -999 relative to the transcription start site of the rat CYP1A1 inserted in a vector containing the herpex simplex virus thymidine kinase (TK) promoter and the luciferase reporter gene) (Nordeen et al., 1998) or pT81 (same reporter plasmid without the XRE sequence, used as a negative control) (Berghard et al., 1993). After $24 \mathrm{~h}$, transfected cells were treated with $10 \mathrm{nM}$ TCDD; $0.1 \mu \mathrm{M}$ 5F203, $1 \mu \mathrm{M}$ 5F203, $0.1 \mu \mathrm{M}$ 5F203 plus $1 \mu \mathrm{M} \alpha-$ naphthoflavone $(\alpha-N F)$ or $1 \mu \mathrm{M} 5 \mathrm{~F} 203$ plus $1 \mu \mathrm{M} \alpha-\mathrm{NF}$, as indicated. Control cells were transfected with pTX.Dir and treated with DMSO (0.1\%). After $18 \mathrm{~h}$ treatment, luciferase activity was measured by the Dual-Luciferase Assay System (Promega) following manufacturer's instructions. Transfection efficiency was monitored by $R$. reniformis luciferase activity using the pRL-TK plasmid as an internal control. 


\section{Measurement of intracellular reactive oxygen species}

Intracellular ROS were measured using the fluorescent dye $2^{\prime}, 7^{\prime}$-dichlorodihydrofluorescein diacetate $\left(\mathrm{H}_{2} \mathrm{DCF}-\mathrm{DA}\right.$; Sigma). Cells were treated with $0.1 \%$ DMSO or 5F203. DCF fluorescence intensity (measured by flow cytometry or fluorometry) is proportional to the amount of intracellular ROS. In selected experiments, cells were treated with $\alpha$-NF $(1 \mu \mathrm{M})$, N-acetyl-cystein (NAC) (100 $\mathrm{mM})$ or Trolox $(250 \mu \mathrm{M})$ for 30 min prior to $5 \mathrm{~F} 203$ treatment. As a positive control $500 \mu \mathrm{M} \mathrm{H}_{2} \mathrm{O}_{2}$ was used.

\section{4, 6-Diamidino-2-phenylindole (DAPI) staining}

Cells were seeded at $2.5 \times 10^{5}$ in $35 \mathrm{~mm}$ dishes o/n, then exposed to DMSO $(0.1 \%)$ or 5 F203 (1 $\mu \mathrm{M}$ ) for $24 \mathrm{~h}$ or $48 \mathrm{~h}$. Floating cells were collected by cytocentrifugation. Once fixed, cells were stained with 0.4\% DAPI and observed under a fluorescence microscope. Experiments were repeated $\geq 3 \mathrm{x}$. Condensed and fragmented nuclei were considered apoptotic.

\section{Determination of pERK, pJNK and pp38}

Western blot analyses were performed using total lysates of cells treated with 5F203 $(1 \mu \mathrm{M})$ for 1 h, $3 \mathrm{~h}$ and $6 \mathrm{~h}$ using pERK, ERK and pJNK antibodies of Santa Cruz (sc-7383 and sc-135900, 1:200, sc-6254, 1:500, respectively), JNK antibody (Cell Signaling \#9258, 1:1000), pp38 antibody (Cell Signaling \#9211, 1:500) and p38 antibody (Cell Signaling \#9217, 1:1000). .

\section{Determination of Caspase 3 and PARP}

Western blot analyses were performed using total lysates of cells treated with 5F203 $(1 \mu \mathrm{M})$ for 30 min, $1 \mathrm{~h}, 3 \mathrm{~h}, 6 \mathrm{~h}, 24 \mathrm{~h}$ and $48 \mathrm{~h}$ using caspase 3 antibody of Santa Cruz (sc-7841; 1:200) and poly(ADP-ribose) polymerase (PARP) Pharmingen, Becton Dickinson, Mountain View, CA, USA $(556494 ; 1: 500)$. 


\section{Determination of p-p53 and p21}

Western blot analyses were performed as described by Chomczynski and Sacchi, 1987, on lysates of cells treated with 5F203 $(1 \mu \mathrm{M})$ for $30 \mathrm{~min}, 1 \mathrm{~h}, 3 \mathrm{~h}, 6 \mathrm{~h}, 24 \mathrm{~h}$ and $48 \mathrm{~h}$ using antibodies to p-p53 (Ser 392) Chemicon (Millipore, Billerica, MA, USA, AB4060; 1: 600) and p21 Cell Signaling Technology, Beverly, MA, USA (Cat \#2946; 1: 500).

\section{Flow cytometry}

Exponentially growing IGROV-1 cells were exposed to $0.1 \%$ DMSO (control) or 5F203 (1 $\mu \mathrm{M})$ for $24 \mathrm{~h}, 48 \mathrm{~h}$, or pre-incubated for $1 \mathrm{~h}$ with $\alpha$-NF $(1 \mu \mathrm{M})$ followed by $24 \mathrm{~h}$ or $48 \mathrm{~h}$ of $5 \mathrm{~F} 203+\alpha-\mathrm{NF}(1$ $\mu \mathrm{M})$. Exponentially growing SKOV-3 cells were exposed to $0.1 \%$ DMSO or 5F203 $(1 \mu \mathrm{M})$ for $24 \mathrm{~h}$ or 48 h. Thereafter, cells were harvested, washed in PBS, and fixed in $70 \%$ ethanol. DNA was stained by incubating cells in PBS containing propidium iodide; fluorescence was measured and analyzed using Cyflogic software version 1.2.1.

\section{Determination of Cyclin D1}

Western blot analyses were performed using total lysates of cells treated with 5F203 $(1 \mu \mathrm{M})$ for 30 min, 1 h, 3 h, 6 h, 24 h and 48 h using anti-Cyclin D1 (Thermo Fisher Scientific, Kalamazoo, MI, USA, cat \# RB-9041, rabbit Ab, 1:10000).

\section{Evaluation of CYP1A1 expression}

Total RNA was isolated using Trizol Reagent (Chomczynski and Sacchi, 1987). RNA concentration was estimated by measuring the optical density at $260 \mathrm{~nm}$ and $2 \mu \mathrm{g}$ RNA was reverse transcribed by using i-Script cDNA synthesis Kit.

Real-Time PCR for CYP1A1 was performed in a $25 \mu 1$ mixture containing cDNA $(1 \mu 1), 0.20 \mathrm{mM}$ dNTPs, specific primers (Sanada et al., 2009) were used at $0.25 \mu \mathrm{M}, 3 \mathrm{mM} \mathrm{MgCl} 2,1 \mathrm{U}$ Taq DNA polymerase and 1:30,000 SYBR Green Stain. Real-Time PCR reactions were performed in a C1000 
Thermal Cycler (Biorad) and the amplification program consisted of an initial denaturing step $\left(94^{\circ} \mathrm{C}\right.$ for $5 \mathrm{~min}$ ), followed by 40 cycles (each of $94^{\circ} \mathrm{C}$ for $30 \mathrm{~s}, 60^{\circ} \mathrm{C}$ for $30 \mathrm{~s}$ and $72^{\circ} \mathrm{C}$ for $30 \mathrm{~s}$ ). Sample quantification was normalized to endogenous GAPDH which was also quantified by RealTime PCR (Mc Kinney and Robbins, 1992), following the same protocol as that for CYP1A1. Fluorescence signal acquisition was carried out at the end of the elongation step. Each assay included a DNA minus control. All samples were run in duplicate and the experiment repeated 3x with independently isolated RNA. RNA expression changes were calculated using the $2-\Delta \Delta C t$ method.

\section{Statistical Analyses}

Statistical significance between 3 or more groups was calculated by one-way analysis of variance (ANOVA) followed by Tukey's test. To compare 2 groups, the unpaired Student's $t$ test with Welch correction was used. Statistical analysis was performed using GraphPad InStat version 3.06 for Windows 95, GraphPad software, San Diego, California, USA, www.graphpad.com. Designations for statistical significance are $* p<0.05,{ }^{*} \mathrm{p}<0.01$ and $* * * p<0.001$.

\section{Results}

5F203 induces AhR translocation and activation of CYP1A1-Related Promoter Sequences in 5F203-sensitive ovarian cancer cells

It has been established that 5F203 is a potent AhR ligand (Bazzi et al, 2009) able to induce nuclear translocation of AhR with subsequent binding to xenobiotic responsive elements (XRE sequences) and transcriptional activation of target genes including CYP1A1 and CYP1B1 in breast cancer cells sensitive to this agent (Loaiza-Perez et al., 2002). As 5F203 causes IGROV-1 cytotoxicity (Supplementary Fig. 1) and consistent with the hypothesis that 5F203 is an AhR agonist ligand (Bradshaw et al., 2008), we wished to determine whether 5F203 activates AhR signaling in IGROV-1 cells with resulting AhR translocation from cytoplasm to nucleus. 
The effect of 5F203 $(1 \mu \mathrm{M})$ on subcellular distribution of immunoreactive AhR protein was studied by Western blot. As demonstrated (Fig. 1B), in IGROV-1 cells treated with DMSO only, the cytoplasmic fraction contained relatively high levels of AhR protein compared with the nuclear fraction. In contrast, after treatment of cells with AhR agonists, $1 \mu \mathrm{M} 5 \mathrm{~F} 203$ or $10 \mathrm{nM}$ TCDD (positive control), between 1 and $6 \mathrm{~h}$, immunoreactive AhR protein could be detected in the nuclear fraction, indicating AhR translocation has taken place.

To identify whether 5F203 caused AhR nuclear translocation in 5F203-insensitive ovarian carcinoma cells, the effect of 5F203 $(1 \mu \mathrm{M})$ on subcellular distribution of immunoreactive AhR protein was assessed by Western blot in SKOV-3 cells. In DMSO-treated cells, AhR protein levels were high in cytoplasmic and nuclear fractions. After treatment with $1 \mu \mathrm{M} 5 \mathrm{~F} 203(0.5-6 \mathrm{~h}), \mathrm{AhR}$ protein in SKOV-3 cytoplasm remained unchanged - AhR was already present in SKOV-3 nuclei, further translocation to the nuclear fraction was negligible. After treatment with TCDD, although cytoplasmic AhR was lost, there was no evidence of AhR gain in nuclear fractions (Fig. 1B). These results were confirmed by inmmunofluorescence of AhR (pictures obtained by confocal microscopy are shown in supplementary Fig. 2). It was then logical to investigate putative activation of CYP1A1-related promoter sequences in 5F203 sensitive ovarian cancer cells. CYP1A1 and CYP1B1 promoters are regulated by AhR, which forms a heterodimer with the AhR nuclear transporter (ARNT). Binding of the complete dimer to XRE promoter regions mediates transcription of AhR-responsive genes, including CYP1A1. IGROV-1 and SKOV-3 were transfected with XRE-luciferase reporter construct (pTX.Dir), as a control, the same reporter construct without XRE elements (pT81) was used. Cells were then treated with $0.1 \%$ DMSO, 0.1-1 $\mu \mathrm{M}$ 5F203 or TCDD $10 \mathrm{nM}$. In IGROV-1 cells transfected with pTX.Dir, 5.5-fold induction of luciferase activity was observed when cells were treated with $1 \mu \mathrm{M} 5 \mathrm{~F} 203$ (Fig. 1C). No induction in luciferase activity was observed when SKOV-3 cells transfected with pTX.Dir were treated with 5F203 $(1 \mu \mathrm{M})$. Cells transfected with pT81 and treated with $1 \mu \mathrm{M}$ 5F203 showed negligible luciferase activity induction (1.1-fold). These findings clearly demonstrate that 5F203 induces 
activation of promoter sequences known to respond to AhR-mediated signals. This is consistent with interaction of protein complexes induced by treatment with 5F203 through the XRE CYP1A1 promoter sequence.

In IGROV-1 cells pre-treated for $1 \mathrm{~h}$ with AhR antagonist $\alpha$-NF $(1 \mu \mathrm{M})$ followed by co-treatment (18 h) with 5F203 plus $1 \mu \mathrm{M} \alpha-\mathrm{NF}$, reduced induction (2.65-fold) of luciferase activity was observed. These results corroborate involvement of AhR in increased XRE-luciferase activity.

\section{F203-induced ROS and $\gamma \mathrm{H} 2 \mathrm{AX}$ foci formation in sensitive cells is mediated by AhR}

Previous studies demonstrated CYP1A1 induction by 5F203, and 5F203 biotransformation to DNA reactive species (Wang and Guengerich, 2012). CYP activity contributes to increased intracellular ROS (Vibhuti et al., 2010). Oxidative stress is involved in various biological processes including proliferation and apoptosis. Therefore, we compared the effect of 5F203 on ROS production in benzothiazole-sensitive IGROV-1 cells and -insensitive SKOV-3 cells. To determine whether 5F203 altered intracellular ROS levels, we treated cells with 5F203 $\leq 6 \mathrm{~h}$ and exposed them to 2,7DCF before evaluating ROS levels using flow cytometry. 5F203 increased ROS in IGROV-1 cells only. This effect, detectable following $1 \mathrm{~h} 1 \mu \mathrm{M}$ 5F203 treatment was partially blocked by preincubation of cells with $\alpha$-NF (Fig. 2A). Also, pre-treatment with ROS inhibitors N-acetyl cysteine (NAC) and Trolox, partially decreased the effect of 5F203 in IGROV-1 cells (Fig. 2B). In contrast, 5F203 strongly inhibited ROS production in SKOV-3 cells, despite detection of neither phenotypic changes nor AhR translocation. It is reported that ROS may cause activation of nuclear factor

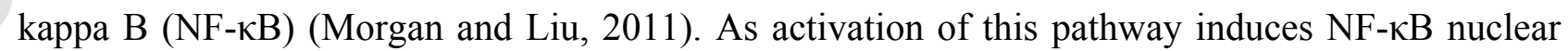
translocation, we performed immunostaining of NF- $\mathrm{BB}$ using a specific antibody in IGROV-1 and SKOV-3 cells before and after treatment with 5F203. 5F203 induced NF- $\kappa$ B translocation in IGROV-1 cells only, and this effect was prevented by pre-treatment of cells with $1 \mu \mathrm{M} \alpha-\mathrm{NF}$ (Supplementary Fig.3). 
We then investigated whether 5F203 caused DNA damage. To determine DNA double strand breaks (DSB), $\gamma \mathrm{H} 2 \mathrm{AX}$ foci were measured in IGROV-1 and SKOV-3 cells following exposure to 5F203 (1 $\mu \mathrm{M}, 2-4 \mathrm{~h})$. DNA DSB formation precipitates serine 139 phosphorylation of histone H2AX, producing $\gamma \mathrm{H} 2 \mathrm{AX}$ at DSB sites (Rogakou et al., 2000). $\gamma \mathrm{H} 2 \mathrm{AX}$ foci appeared within nuclei of IGROV-1 cells only following treatment with 5F203 (1 $\mu \mathrm{M}$; 2-4 h; Fig. 2C). Foci formation was partially blocked by pre-treatment of cells with $\alpha-\mathrm{NF}$, confirming that activation of AhR is needed for 5F203-induced DNA damage. In contrast, neither vehicle-treated cells nor SKOV-3 cells challenged with 5F203 displayed $\gamma \mathrm{H} 2 \mathrm{AX}$ foci within their nuclei at any time point examined.

\section{F203 modulates expression and phosphorylation of stress MAPKs.}

Mitogen activated protein kinases (MAPK) can be modulated by many factors including cell lesions induced by DNA damage (Rogakou et al., 2000). We therefore investigated the effect of 5F203 on activation of these protein kinases in IGROV-1 cells. As observed in Figure 3A, 5F203 induced phosphorylation of JNK and P38 (2.26 and 8.16-fold respectively, supp. Fig. 4A), the stronger effect was attained after $6 \mathrm{~h}$ treatment in both cases. Also, treatment with 5F203 increased P38 $\alpha$ expression (2.44-fold - 10.62-fold; 1 h -6 h respectively, supp. Fig. 4A). Pre-treatment of cells with $\alpha$-NF decreased phosphorylation of these kinases and P38 $\alpha$ expression which confirmed that 5F203 affected expression and activation of these proteins through AhR activation. We also observed that $1 \mathrm{~h}$ exposure to 5F203 increased phosphorylation of ERK in IGROV-1 cells (1.44-fold; supplementary Figure 4A).

The ability of 5F203 to induce apoptosis was evaluated. Exposure of IGROV-1 cells to 5F203 (1 $\mu \mathrm{M} ; 24 \mathrm{~h})$ induced apoptotic body formation (Figure 3B). In contrast, SKOV-3 cells, resistant to 5F203, did not show such features (Figure 3B). Also, pre-treatment of cells with $\alpha$-NF partially blocked the pro-apoptotic effect of 5F203 in IGROV-1 cells. These data confirm that AhR is involved in 5F203-induced cell death. 
Trolox (a vitamin E derivative) and NAC are potent ROS scavengers often used as antioxidant agents. We pre-treated IGROV-1 cells with Trolox or NAC in order to investigate the effect of ROS depletion on 5F203-induced growth inhibition. Cells were exposed to 5F203 (1 $\mu \mathrm{M}, 24 \mathrm{~h})$ after pre-treatement with Trolox (250 $\mu \mathrm{M})$ or NAC (100 $\mathrm{mM}$ ) for $1 \mathrm{~h}$. As observed in figure 3B both inhibitors partially reduced 5F203-induced apoptotic body formation. These data reveal the role of ROS in 5F203-induced apoptosis in sensitive IGROV-1 cells.

\section{F203 causes altered cell cycle distribution and apoptosis in sensitive ovarian cancer cells}

As our results indicate that 5F203 induced DNA damage (Fig. 2B), we investigated perturbations in cell cycle. For this approach, IGROV-1 and SKOV-3 cells were exposed to $1 \mu \mathrm{M} 5 \mathrm{~F} 203$ or $0.1 \%$ DMSO for $24 \mathrm{~h}$ and $48 \mathrm{~h}$ and subsequently processed for cell cycle analyses. As illustrated (Fig. 4A), 5F203 caused an increase in G1 phase IGROV-1 cells (44\% control; $50 \%$ at $24 \mathrm{~h}$ and 59\% at $48 \mathrm{~h}$ ), coinciding with decreased G2/M phase cells (20\% control to $13 \%$ at $24 \mathrm{~h}$ and $9 \%$ at $48 \mathrm{~h}$ ). Accumulation of sub-G1 events was also detected from 5\% (control) to $12 \%$ at $24 \mathrm{~h}$ and $20 \%$ at 48 h. When cells were pre-incubated with $\alpha-\mathrm{NF}$ sub-G1 events diminished indicating that AhR activation is necessary for 5F203-induced apoptosis. In contrast, SKOV-3 cell cycle was not perturbed following treatment with 5F203. The data demonstrate that 5F203-induced DNA damage may lead to accumulation of cells in G1 phase concomitant with growth inhibition. As IGROV-1 cells are p53 wild type, their response to 5F203 is consistent with operation of a G1 checkpoint arrest to cell cycle progression after DNA damage.

As G1 phase arrest was observed in 5F203-sensitive cells, we examined cyclin D1 levels after treatment. Results demonstrate that exposure of IGROV-1 cells to 5F203 reduced cyclin D1 protein levels by $50 \%$ and $75 \%$ after $24 \mathrm{~h}$ and $48 \mathrm{~h}$ respectively. In contrast, only a $35 \%$ decrease in cyclin D1 levels was observed in SKOV-3 cells after $48 \mathrm{~h}$ treatment with 5F203 (Fig. 4B). 
In order to study whether 5F203 treatment caused caspase 3 activation, PARP cleavage and p53 phosphorylation in IGROV-1 cells as a result of its pro-apoptotic action, we carried out Western blot experiments upon separated proteins of whole cell lysates following treatment of cells with 1 $\mu \mathrm{M}$ 5F203 between 3-48 h. We observed caspase 3 activation, PARP cleavage and 2.7- and 4-fold increased p53 phosphorylation between $24 \mathrm{~h}$ and $48 \mathrm{~h}$ respectively. A similar pattern of increased p21 protein levels was observed after treatment of IGROV-1 cells with 5F203 (Fig. 4C). In contrast, caspase activation, PARP cleavage and changes in pp53 and p21 protein levels were not detected in SKOV-3 cells treated with 5F203 (Fig.4C).

\section{Cytotoxicity of 5F203 in cells isolated from ovarian cancer ascites is mediated by AhR}

Cancer cells, derived from ascites fluid produced by ovarian tumors from three patients were authenticated by pathologists. All tumors were high grade (G3), serous, papillary histological type. Cells were treated in culture with 5F203 for 5 days and cytotoxicity measured using MTS assays. Two cell strains were sensitive to 5F203 and one was resistant (Fig. 5A). In patient A, $1 \mu \mathrm{M}$ and 10 $\mu \mathrm{M}$ 5F203 decreased cell viability by $40 \%$ and 50\% respectively (compared to control considered $100 \%$ ). This decrease in cell viability diminished to $20 \%$ and $30 \%$ respectively when cells were pre-treated with $1 \mu \mathrm{M} \alpha$-NF followed by incubation with 5F 203/ $\alpha-\mathrm{NF}$. We observed similar results in cells derived from patient B (data not shown). These results indicate that AhR mediates the effect of 5F203 in these papillary tumors sensitive to 5F203 (Fig. 5B). AhR nuclear translocation was then investigated in these ovarian cells. As demonstrated in Fig. 5C, in cells treated with DMSO, high levels of AhR protein was detected in cytosol and nucleus. After treatment with 10 $\mu \mathrm{M}$ 5F203 or $10 \mathrm{nM}$ TCDD for $1 \mathrm{~h}$, immunofluorescent AhR protein increased in the nucleus and decreased in the cytosol. In contrast, constitutive nuclear AhR localization was detected in cells of patient C - resistant to 5F203. CYP1A1 mRNA levels were measured by Real Time PCR in cells from patients A, B (sensitive to 5F203) and C (resistance to 5F203) following exposure to 5F203 (1 $\mu \mathrm{M} ; 24 \mathrm{~h})$. In cells from patients $A$ and $B$, we observed $23.88 \pm 4.07$ - and $2.4 \pm 0.28$-fold induction of CYP1A1 expression, respectively (Fig. 6A), 
which was partially reduced by $\alpha-N F$. In contrast, reduction of CYP1A1 expression was observed after treatment of patient C cells with 5F203. Finally ROS levels were evaluated after treatment of patient ascites cells with 5F203. Increased ROS levels were detected only in cells sensitive to 5F203, ROS were not induced in the 5F203-insensitive ascites cells of patient C (Fig. 6B).

\section{Discussion}

In this paper we show for the first time that 5F203 activates AhR signaling in cultured and patient ovarian carcinoma cells sensitive to this agent, demonstrating that 5F203 cytotoxicity is AhR dependent. In sensitive IGROV-1 cells, 5F203 a known AhR ligand (Bazzi et al., 2009) triggers AhR translocation from cytosol to nucleus, activating CYP1A1-related promoter sequences driving transcription of AhR responsive genes as reported by XRE-luciferase.

It was recognized several years ago that certain ovarian cancer cell lines were exquisitely sensitive to antitumor benzothiazoles (Bradshaw et al., 1998). 5F203 potency and selectivity against ovarian cell lines within the NCI panel have been demonstrated (Bradshaw et al., 1998; Hutchinson et al., 2001): IGROV-1, OVCAR4 and OVCAR5 displayed $\mathrm{GI}_{50}$ values $<100 \mathrm{nM}$ in contrast, $\mathrm{GI}_{50}$ values $>10 \mu \mathrm{M}$ were observed in OVCAR8 and SKOV-3 cells. Subsequently induction of CYP1A1 by 5F203 in sensitive cancer cells only inferred significant correlation between sensitivity and CYP1A1 induction (Hose et al., 2003). In vivo, antitumor activity of 5F203 prodrug Phortress was demonstrated against IGROV-1 tumors. Moreover, CYP1A1 expression was detected in IGROV-1 tumors of mice receiving Phortress treatment. No CYP1A1 protein was detected in insensitive breast tumor tissue following treatment of mice with Phortress (Leong et al., 2004).

Differential sensitivity to 5F203 may be a consequence of differential regulation by AhR of CYP1A1 expression in different cell types. In resistant cells we observed constitutive nuclear localization of AhR. In resistant cells AhR may be associated with co-repressors (Hestermann and Brown, 2003); lack of AhR degradation (by ubiquitination) or recycling may lead to inappropriate AhR function 
(Ma and Baldwin, 2000). Also, different AhR nuclear localization sequences (Ikuta et al. 1998; Ikuta et al., 2000) or polymorphisms may cause inappropriate receptor function (Rowlands et al., 2010). Additionally, mutations in the CYP1A1 promoter in insensitive cells may lead to decreased CYP1A1 activation (Zheng et al., 2010).

Considering the clinical potential of 5F203, its mechanism of action was further investigated. 5F203 induced ROS formation in sensitive cells (Fig. 2). In IGROV-1 cells 5F203 evoked DNA damage detected as $\gamma \mathrm{H} 2 \mathrm{AX}$ foci (2-4 h), increased pp53 levels and P21 expression, decreased cyclin D1 expression, caused G1 cell cycle arrest and apoptosis. In contrast, SKOV-3 cells showed decreased levels of pp53 after treatment with 5F203, the reason for this effect is unclear but it may contribute to cellular resistance to 5F 203 (Fig. 4).

5F203-induced growth inhibition and apoptosis in IGROV-1 cells may in part be a consequence of elevated ROS (Fig. 2A) and caspase 3 activation (Fig. 4C) resulting in oxidative DNA damage and cell death. Oxidative stress may activate caspases and is implicated in a number of cellular processes including apoptosis. Many chemotherapeutic agents are known to induce cytotoxicity by ROS-mediated mechanisms e.g. doxorubicin (Lin et al., 2007) and AhR ligand Aminoflavone (McLean et al., 2006).

It was demonstrated that ROS may trigger apoptosis signaling mediated by p53 in IGROV-1 cells (Righetti et al., 1999; Casinelli et al., 2001). IGROV-1 cells possess wild type p53 and show sensitivity to 5F203. However, 5F203 activity is independent of p53 exemplified by i) potent activity of 5F203 in MDA-MB-468 p53 mutant cells (Bradshaw et al. 1998) ii) IGROV-1 variant populations demonstrating acquired resistance to cisplatin retain sensitivity to 5F203 (Bradshaw et al, unpublished results). Cisplatin resistance is associated with p53 mutations in IGROV-1 cells (Perego et al., 1996). In IGROV-1 cells, p53 may be attempting (failed) repair rather that mediating apoptosis.

Our results show that antioxidant agents such as NAC and Trolox decrease ROS formation and protect IGROV-1 cells from apoptosis induced by 5F203(Fig. 3B). Previous work has demonstrated 
that stress signaling pathways are also activated by cisplatin and retinoids in IGROV-1 and cisplatin-resistant IGROV-1 cells, furthermore activation of JNK and P38 by these agents is stronger in cisplatin-resistant IGROV-1 cells. Reflecting that integral to antitumor activity, 5F203 induces ROS in sensitive IGROV-1 cells and that IGROV-1 cells resistant to cisplatin retain sensitivity to 5F203, we propose that 5F203 could be a putative treatment for ovarian tumors.

MAPK p38 $\alpha$ acts as an oxidative stress sensor; ROS-induced activation of p38 promotes apoptosis and prevents further oncogenic/carcinogenic ROS formation (Mateescu et al., 2011) Also microRNAs (miRNA) expression can be altered by different stress conditions and are well known stress response regulators. It has been described that two members of the miR-200 family, miR-141 and miR-200a, inhibit p38 and have an essential role in the redox response. In animal models, accumulation of miRNAs mimics p38 deficiency and promote malignancy. Human ovarian adenocarcinomas demonstrating high oxidative stress show high expression of miR-200a and low basal levels of $\mathrm{p} 38 \alpha$. Chemotherapy drugs that induce ROS also induce p38 $\alpha$ in these tumors, leading to apoptosis. It was proposed that in ovarian tumors high levels of miR-200s and low levels of $\mathrm{p} 38 \alpha$ could be predictive markers of good clinical response to chemotherapy (Mateescu et al., 2011). Our results are consistent with these observations, IGROV-1 cells have low levels of basal p38 $\alpha$ and treatment with 5F203 induced p38 $\alpha$ expression and pp38 (Fig. 3A), which may lead to apoptosis. In contrast, SKOV-3 cells show high basal levels of p38 $\alpha$ and treatment with 5F203 did not modulate $\mathrm{p} 38 \alpha$ expression or activation (Fig. 3A). We hypothesize that this may contribute to the lack of apoptosis induction in SKOV-3 cells.

Finally, compatible with results from ovarian cancer cell lines, we identified putative in vitro surrogate markers of sensitivity to 5F203 in a small sample of patient tumors. Clear distinction was demonstrated between ovarian cancer patient tumor cells that were sensitive to 5F203 and those which were inherently 5F203-resistant. Only in ascitesisolated patient tumor cells sensitive to $5 \mathrm{~F} 203$ was i) cytosolic AhR translocation to cell 
nuclei, ii) CYP1A1 mRNA induction, iii) increased ROS levels observed (Fig. 5 and 6) in response to ex vivo treatment. Such pharmacodynamic endpoints are readily obtained from bioassays that could be adopted clinically to detect candidate 5F203-responsive patients. In this way, unresponsive patients would be spared unnecessary treatment. Sensitivity to 5F203, and AhR activation should be examined in a larger sample of ovarian carcinoma patient tumors of different histological types in future studies. However, the fact that cells isolated from patients with high grade ovarian tumors were sensitive to 5F203 shows that this agent may offer alternative treatment for patients with advanced disease. Intraperitoneal (i.p.) chemotherapy is currently used in treatment of ovarian tumors and both 5F203 and its prodrug Phortress have demonstrated antitumor efficacy administered either intravenously or i.p. (Bradshaw et al, 2002; Hose et al., 2003).

In summary, we have demonstrated AhR-dependent cytotoxicity of 5F203 in ovarian carcinoma cells, we conclude that AhR may represent a new molecular target in the treatment of ovarian cancer and that 5F203 may offer a potential novel treatment for this disease.

\section{Acknowledgements}

We want to thank Drs. Andrea Randi (School of Medicine, University of Buenos Aires, Argentina) and Leonor Roguin (School of Pharmacy, University of Buenos Aires, Argentina) for the donation of antibodies and reagents.

Statement of Conflict of Interest: TDB is listed as inventor on patents covering the intellectual property of 5F203 and is consultant and shareholders of Pharminox Ltd which has commercial interest in antitumor benzothiazoles.

The rest of the authors indicate no potential conflicts of interest 


\section{Literature cited}

Bazzi R, Bradshaw TD, Rowlands C, Stevens MFG, Bell D. 2009. 2-(4-Amino-3-methylphenyl)-5fluorobenzothiazole is a ligand and shows species-specific partial agonism of the aryl hydrocarbon receptor. Toxicol Appl Pharmacol 237:102-110.

Berghard A, Gradin K, Pongratz I, Whitelaw M, Poellinger L. 1993. Cross-coupling of signal transduction pathways: the dioxin receptor mediates induction of cytochrome P-450IA1 expression via a protein kinase C-dependent mechanism. Mol Cell Biol 13:677-689.

Bradshaw TD, Shi D-F, Schultz RJ, Paull KD, Kelland L, Wilson A, Garner C, Fiebig HH, Wrigley S, Stevens MF. 1998. Influence of 2-(4-aminophenyl)benzothiazoles on growth of human ovarian carcinoma cell lines in vitro and in vivo. Br J Cancer 78:421-29.

Bradshaw TD, Bibby MJ, Double JA, Fitchner I, Cooper PA, Alley MC, Donohue S, Stinson SF, Tomaszewiski JE, Sausville EA, Stevens MF. 2000. Preclinical evaluation of amino acid prodrugs of novel antitumor 2-(4-amino-3-methylphenyl)benzothiazoles. Mol Cancer Ther 1:239-46.

Bradshaw TD, Stone EL, Trapani V, Leong C-O, Matthews CS, te Poele R, Stevens MF. 2008. Mechanisms of acquired resistance to 2-(4-Amino-3-methylphenyl)benzothiazole in breast cancer cell lines. Breast Cancer Res Treat 110: 57-68.

Bradshaw TD, Stevens MFG, Calvert H, Plummer R. 2009. Clinical Trials: Poster Presentations. Abstract B59: Preliminary clinical experiences of Phortress: Putative role for c-MET inhibition in antitumor activity. AACR-NCI-EORTC International Conference: Molecular Targets and Cancer Therapeutics--Nov 15-19, 2009; Boston, MA. Molecular Cancer Therapeutics: December 2009; Volume 8, Issue 12, Supplement 1, doi: 10.1158/1535-7163.

Cassinelli G, Supino R, Perego P, Polizzi D, Lanzi C, Pratesi G, Zunino F. 2001. A role for loss of p53 function in sensitivity of ovarian carcinoma cells to taxanes. Int J Cancer 92: 738-747. 
Chomczynski P, Sacchi N. 1987. Single-step method of RNA isolation by acid guanidiniumthiocyanate-phenol-chloroform extraction. Anal Biochem 162: 156-159.

Fichtner I, Monks A, Hose C, Stevens MFG, Bradshaw TD. 2004. The experimental antitumor agent Phortress and doxorubicin are equiactive against human-derived breast carcinoma xenograft models. Breast Cancer Res Treat 87: 97-107.

Hestermann EV, Brown M. 2003. Agonist and chemopreventative ligands induce differential transcriptional cofactor recruitment by aryl hydrocarbon receptor. Mol. Cell. Biol. 23:7920-7925.

Hose CD, Hollingshead M, Sausville EA, Monks A. 2003. Induction of CYP1A1 in tumor cells by the antitumor agent 2-[4-amino-3-methylphenyl]-5-fluoro-benzothiazole: a potential surrogate marker for patient sensitivity. Mol Cancer Ther. 2:1265-72.

Hutchinson I, Chua M-S, Browne HL, Trapani V, Bradshaw TD, Westwell AD, Stevens MF, 2001. The synthesis and in vitro biological properties of fluorinated 2-(4-aminophenyl)benzothiazoles. J Med Chem 44: 1446-55.

Ikuta T, Eguchi H, Tachibana T, Yoneda Y, Kawajiri K. 1998. Nuclear localization and export signals of the human aryl hydrocarbon receptor. J Biol Chem 273:2895-2904.

Ikuta T, Tachibana T, Watanabe J, Yoshida M, Yoneda Y, Kawajiri K. 2000. Nucleocytoplasmic shuttling of the aryl hydrocarbon receptor. J Biochem 127:503-509.

Lin X, Li Q, Wang YJ, Ju YW, Chi ZQ, Wang MW, Liu JG. 2007. Morphine inhibits doxorubicininduced reactive oxygen species generation and nuclear factor kappaB transcriptional activation in neuroblastoma SH-SY5Y cells. Biochem J 406: 215-21.

Leong C-O, Suggitt M, Swaine MJ, Bibby MC, Stevens MFG, Bradshaw TD. 2004. In vitro, in vivo and in silico analyses of the antitumor activity of 2-(4-amino-3-methylphenyl)-5fluorobenzothiazoles. Mol Cancer Therap 3:1565-75.

Loaiza-Perez AI, Trapani V, Hose C, Singh SS, Trepel JB, Stevens MFG, Bradshaw TD, Sausville EA. 2002. Aryl hydrocarbon receptor mediates sensitivity of MCF-7 breast cancer cells to the antitumor agent 2 - (4-amino-3-methylphenyl) benzothiazole. Mol Pharmacol 61: 13-9. 
Ma Q, Baldwin KT. 2000. 2,3,7,8-Tetrachloro-dibenzo-p-dioxin-degradation of the aryl hydrocarbon receptor (AhR) by the ubiquitin proteosome-pathway. J Bio Chem 275: 8432-8438.

Mateescu B, Batista L, Cardon M, Gruosso T, de Feraudy Y, Mariani O, Nicolas A, Meyniel J-P, Cottu P, Sastre-Garau X, Mechta-Grigoriou F. 2011. miR-141 and miR-200a act on ovarian tumorigenesis by controlling oxidative stress response. Nat Med 17:1627-1635.

Mc Kinney M, RobbinsM. 1992. Chronic atropine administration up-regulatesrat-cortical muscarinic $\mathrm{m} 1$ receptor mRNA molecules: assessment with the RT/PCR. Brain Res Mol Brain Res 12: $39-45$.

McLean L, Davis W Jr, Sowers E, Brantley EJ. 2006. 5F 203-induced apoptosis involves oxidative stress and caspase activation in sensitive breast cancer cells. American Association for Cancer Research (AACR), Washington DC, USA

Morgan MJ, Liu Z. 2011. Crosstalk of reactive oxygen species and NF-kB signaling. Cell Res 21:103-15.

Nordeen SK. 1998. Luciferase reporter gene vectors for analysis of promoter and enhancers. Biotechniques 6: 454-57.

Perego P, Giarola M, Righetti SC, Supino R, Caserini C, Delia D, Pierotti MA, Miyashita T, Reed JC, Zunino F. 1996. Association between cisplatin resistance and mutation of p53 gene and reduced bax expression in ovarian carcinoma cell systems. Cancer Res 56: 556-62.

Righetti SC, Perego P, Corna E, Pierotti MA, Zunino F. 1999. Emergence of p53 mutant cisplatinresistant ovarian carcinoma cells following drug exposure: spontaneously mutant selection. Cell Growth Differ 10: 473-478.

Rogakou EP, Nieves-Neira W, Boon C, Pommier Y, Bonner WM. 2000. Initiation of DNA fragmentation during apoptosis induces phosphorylation of $\mathrm{H} 2 \mathrm{AX}$ histone at serine 139 . J Bio Chem 275: 9390-5.

Romero I, Bast RC Jr. 2012. Minireview: human ovarian cancer: biology, current management, and paths to personalizing therapy. Endocrinology 153:1593-602. 
Rowlands CJ, Staskal DF, Gollapudi B, Budinsky R. 2010. The human AHR: identification of single nucleotide polymorphisms from six ethnic populations. Pharmacogenet Genomics 20:28390.

Sanada N, Gotoh Y, Shimazawa R, Klinge CM, Kizu R. 2009. Repression of activated aryl hydrocarbon receptor-induced transcriptional activation by $5 \alpha$-dihydrotestosterone in human prostate cancer LNCaP and human breast cancer T47D Cells. J Pharmacol Sci 109: 380 - 387.

Shepherd TG, Thériault BL, Campbell EJ, Nachtigal MW. 2006. Primary culture of ovarian surface epithelial cells and ascites-derived ovarian cancer cells from patients. Nat Prot 1: 2643-2649.

Tandon VR, Sharma S, Mahajan A, Bardi GH. 2005. Oxidative stress: novel strategy in cancer treatment. JK Sci 7:1-3.

Vathipadiekal V, Saxena D, Mok SC, Hauschka PV, Ozbun L, Birrer MJ. 2012. Identification of a potential ovarian cancer stem cell gene expression profile from advanced stage papillary serous ovarian cancer. PLoS ONE,; 7 (1): e29079. doi:10.1371/journal.pone.0029079.

Vibhuti A, Arif E, Mishra A, Deepak D, Singh B, Rahman I, Mohammad G, Qadar Pasha MA. 2010. CYP1A1, CYP1A2 and CYBA gene polymorphisms associated with oxidative stress in COPD. Clin Chim Acta 411:474-80.

Wang K, Guengerich FP. 2012. Bioactivation of fluorinated 2-aryl-benzothiazole antitumor molecules by human cytochrome P450s $1 \mathrm{~A} 1$ and 2W1 and deactivation by cytochrome P450 2S1. Chem Res Toxicol 25: 1740-1751

Zheng Q, Sha X, Liu J, Heath E, Lorusso P, Li J. 2010. Association of human cytochrome P450 1A1 (CYP1A1) and sulfotransferase 1A1 (SULT1A1) polymorphisms with differential metabolism and cytotoxicity of aminoflavone. Mol Cancer Ther 9:2803-13.

Ziech D, Franco R, Pappa A, Panayiotidis MI. 2011. Reactive oxygen species (ROS)-induced genetic and epigenetic alterations in human carcinogenesis. Mutat Res 711:167-73. 
Zuco V, Zanchi C, Cassinelli G, Lanzi C, Supino R, Pisano C, Zanier R, Giordano V, Garattini, 2004. Induction of apoptosis and stress response in ovarian carcinoma cell lines treated with ST1926, an atypical retinoid. Cell Death Differ; 11: 280-9. 


\section{Figures:}

\section{Figure 1.}

5F203 induces AhR nuclear translocation and activation of CYP1A1-Related Promoter Sequences in sensitive ovarian cancer cell lines. A. Chemical structure of antitumor 2-(4-amino-3-methylphenyl)-5-

fluorobenzothiazole. B. AhR Subcellular localization. IGROV-1 and SKOV-3 cells were incubated with 5F203 $(1 \mu \mathrm{M})$ for indicated times, DMSO $(0.1 \%)$ for $6 \mathrm{~h}$ or TCDD $(10 \mathrm{nM})$ for $1 \mathrm{~h}$ as a positive control. Nuclear and cytosolic fractions were isolated using a commercial kit and analyzed for AhR content by Western blot. The figure shows representative Western blots. All Western blots were performed three times for each cell line and revealed the same pattern of AhR subcellular distribution. C. Activation of CYP1A1-Related Promoter Sequences. Cells were transfected with a plasmid containing XRE (AhR consensus sequences) upstream of the luciferase reporter gene and a second plasmid containing $R$. reniformis luciferase gene as an internal control. After $24 \mathrm{~h}$, cells were incubated with $5 \mathrm{~F} 203$ for $18 \mathrm{~h}$ or pre-treated for $1 \mathrm{~h}$ with $1 \mu \mathrm{M}$ a-NF followed by 18 h 5F203 plus $1 \mu \mathrm{M}$ a-NF. Luciferase activity was determined using the Dual-Luciferase Reporter Assay System (Promega). Values represent the average of thr

\section{Figure 2.}

5F203 increases ROS levels. Exponentially growing IGROV-1 and SKOV-3 cells were treated with 5F203 (1 $\mu \mathrm{M})$ or vehicle control ( $0.1 \%$ DMSO) continuously for $1 \mathrm{~h}, 2 \mathrm{~h}, 4 \mathrm{~h}$ or $6 \mathrm{~h}$ and ROS levels were measured by flow cytometry after incubation with 2,7-DCF. Data represent the mean of at least two independent experiments where $\mathrm{n}=2$ per experiment; bars, SEM. ${ }^{*} \mathrm{p}<0.05$ when compared to untreated cells, $* * \mathrm{p}<$ 0.05 when compared to cells treated without AhR inhibitor. B. Trolox and NAC inhibition of 5F203-mediated ROS induction. IGROV-1 cells were exposed to $0.1 \%$ DMSO (control), 5F203 (1 $\mu \mathrm{M})$ for 1 or $2 \mathrm{~h}$, or pretreated with Trolox $(250 \mu \mathrm{M})$ or NAC $(100 \mathrm{mM})$ for $1 \mathrm{~h}$ followed by $5 F 203(1 \mu \mathrm{M})+$ Inhibitor for 1 or $2 \mathrm{~h}$. ROS levels were measured by fluorometry after incubation with 2,7-DCF. Data represent the mean of at least two independent experiments where $\mathrm{n}=2$ per experiment; bars, SEM. $* \mathrm{p}<0.05$ or $* * \mathrm{p}<0.01$ when compared to cells treated without ROS inhibitor. C. induces $\mathrm{YH} 2 \mathrm{AX}$ foci formation in sensitive IGROV-1 cells. A. Measurement of ROS levels. YH2AX foci following 2-4 h treatment of cells with 5 F203 (1 $\mu$ M); IGROV-1 cell nuclei were stained with DAPI. Stained cells were visualized on a fluorescence Nikon C1 confocal microscope using a 60X PlanApo AN 0.95 objective, images were processed and analyzed with Nikon C1-EZ packaqe, version 2.20 .

\section{Figure 3.}

5F203 induces MAPKs activation and apoptosis in sensitive IGROV-1 cells. A. MAPKs expression and activation. IGROV-1 and SKOV-3 cells were incubated with 5 F203 $(1 \mu \mathrm{M})$ for indicated times or DMSO $(0.1 \%)$ for $6 \mathrm{~h}$. Whole cell extracts were obtained and subjected to SDS-PAGE and Western blotting with pERK, ERK, pJNK, JNK, pp38 and p38 $\alpha$ antibodies. The figure shows representative Western blots. All

Western blots were performed three times for each cell line and revealed the same pattern of protein phosphorylation and expression. B. Evaluation of cell apoptosis. Cells were incubated with $1 \mu \mathrm{M} 5 \mathrm{~F} 203$ or DMSO $(0.1 \%)$ for $24 \mathrm{~h}$ or pre-treated with $\alpha$-NF $(1 \mu \mathrm{M})$ Trolox $(250 \mu \mathrm{M})$ or NAC $(100 \mathrm{mM})$ for $1 \mathrm{~h}$ followed by 5 F203 $(1 \mu \mathrm{M})+$ Inhibitor for $24 \mathrm{~h}$. Then, non-adherent cells were obtained by cytocentrifuqation in the culture medium. Once fixed, cells were stained with DAPI and observed under a fluorescence microscope.

Condensed and fragmented nuclei were considered apoptotic. Representative fields are shown. 


\section{Figure 4.}

5F203 induces AhR dependent cell cycle arrest in G1 phase, a decrease in cyclin D1 and caspase-3 mediated apoptosis in sensitive ovarian cancer cells. A. Exponentially growing IGROV-1 cells were exposed to either $0.1 \%$ DMSO (control) or $5 \mathrm{~F} 203(1 \mu \mathrm{M})$ for $24 \mathrm{~h}, 48 \mathrm{~h}$, (upper panel) or pre-incubated for $1 \mathrm{~h}$ with a-NF followed by $24 \mathrm{~h}$ or $48 \mathrm{~h} \mathrm{5F} \mathrm{203+a-NF}(1 \mu \mathrm{M})$ (lower panel). Exponentially growing SKOV-3 cells were exposed to either $0.1 \%$ DMSO (control) or 5F203 $(1 \mu \mathrm{M})$ for $24 \mathrm{~h}$ or $48 \mathrm{~h}$. Then both cell lines were harvested, washed in PBS, and fixed in 70\% ethanol. DNA was stained by incubating cells in PBS containing propidium iodide and fluorescence measured and analyzed as described in Materials and Methods. The experiment was repeated three times (significant difference between treatments with $p<0.01$ ). Data of one representative experiment is shown in the figure. B. Effect of 5F 203 on Cyclin D1 expression. IGROV-

1 cells were exposed to either $0.1 \%$ DMSO (control) or $5 F 203(1 \mu \mathrm{M}$ ) for $3 \mathrm{~h}, 6 \mathrm{~h}, 24 \mathrm{~h}$ or $48 \mathrm{~h}$. Proteins in total lysates were resolved by SDS-PAGE and Western Blot performed with anti- cyclin D1 Ab. Anti-actin Ab was used as a loading control. C. Effect of 5F203 on p53 signaling pathway, caspase 3 activation and PARP cleavage in ovarian cancer cells. Cells were incubated with $1 \mu \mathrm{M} 5 \mathrm{~F} 203$ during indicated times or TCDD (T) $10 \mathrm{nM}$ for $1 \mathrm{~h}$. Cells treated with $10 \mu \mathrm{M}$ Etoposide (Et) were used as a positive control for apoptosis. Whole cell extracts were obtained and subjected to SDS-PAGE and Western blotting with p-P53 and P21, caspase 3 and PARP antibodies. p-P53, phosphorylated form of P53.

\section{Figure 5.}

5F203 activity in ascites-derived ovarian cancer cell strains isolated from patients. A. 5F203 cytotocixity assay. Cells derived from three patients were incubated with $5 F 203$ for 5 days. Cellular viability was evaluated by MTS assay. Values represent the average of two independent experiments using cells from one patient $(n=4), * p<0.05$ compared with untreated cells. B. Cells derived from patient A (sensitive to 5F203) were incubated with $5 F 203$ for 5 days or pre-treated for $1 \mathrm{~h}$ with a-NF $(1 \mu \mathrm{M})$ and then treated with $5 \mathrm{~F} 203$ plus a-NF $(1 \mu \mathrm{M})$ for 5 days. Cellular viability was evaluated by MTS assay. The values represent the average of two independent experiments using cells from one patient $(n=4), * * p<0.01$ compared with cells incubated without AhR inhibitor. C. 5F203 induces translocation of AhR to the nucleus in sensitive ascitesderived ovarian cancer cells. The staining of cells from one representative patient is shown. Cells were grown on coverslips and treated with DMSO for $1 \mathrm{~h}, 5 \mathrm{~F} 203$, for 30 minutes or a-NF $1 \mu \mathrm{M}$ followed by $1 \mathrm{~h}$ of $5 F 203+a-N F 1 \mu M$, or $10 \mathrm{nM}$ TCDD for $1 \mathrm{~h}$. After fixation, cells were double stained for AhR (green) and propidium iodide (red). Cells treated with $10 \mathrm{nM}$ TCDD were incubated only with 20 antibody to determine non-specific background. Stained cells were visualized on a fluorescence microscope using a 40X PlanApo AN

0.95 objective, and images were processed and analyzed with Nikon C1-EZ package, version 2.20.

\section{Figure 6.}

5F203 induces CYP1A1 over-expression and increases ROS level in sensitive ascites-derived ovarian cancer cells isolated from patients. A. Induction of CYP1A1 gene expression. Cells derived from three patients were cells were exposed to $0.1 \%$ DMSO (control), 5 F203 $(1 \mu \mathrm{M})$ for $24 \mathrm{~h}$, or pre-treated with $\alpha$-NF $(1 \mu \mathrm{M})$ for $1 \mathrm{~h}$ followed by $5 F 203(1 \mu \mathrm{M})+\alpha-N F(1 \mu \mathrm{M})$ for $24 \mathrm{~h}$. RNA was isolated and real-time PCR were performed to measure CYP1A1 expression. A. Each bar represents mean \pm SD of triplicate measurements in drugtreated, compared to untreated, cells using GAPDH expression as an endogenous control. * p $<0.01$ or \# $<0.05$ when comparing to untreated cells ** $\mathrm{p}<0.01$ or \#\# $\mathrm{p}<0.05$ when comparing to cells treated without AhR inhibitor. B. Measurement of ROS levels. Cells derived from three patients were cells were treated with 5F203 $(1 \mu \mathrm{M})$ or vehicle control $(0.1 \%$ DMSO) continuously for $1 \mathrm{~h}$ or $2 \mathrm{~h}$ and ROS levels were measured by fluorometry after incubation with 2,7-DCF. Incubation with H2O2 (100 mM) was used as positive control. Data represent the mean of at least two independent experiments where $n=2$ per experiment; bars, SEM. ${ }^{*} \mathrm{p}<0.05, * * \mathrm{p}<0.01$ when compared to untreated cells. 
A<smiles>Cc1cc(-c2nc3cc(F)ccc3s2)ccc1N</smiles>

IGROV-1

B $\underset{\text { FRACTION }}{\text { CYTOLIC }}$

NUCLEAR FRACTION
SKOV-3

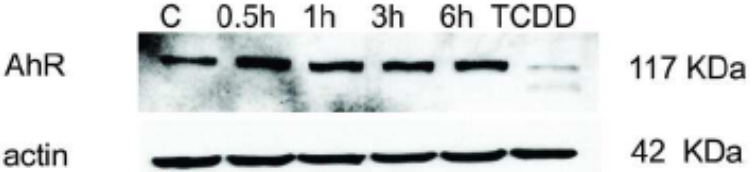

AhR

actin
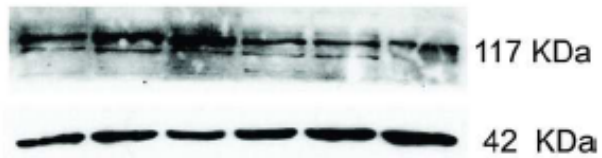

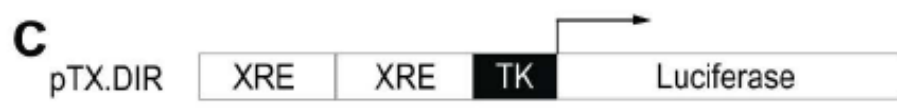

pT81 TK Luciferase
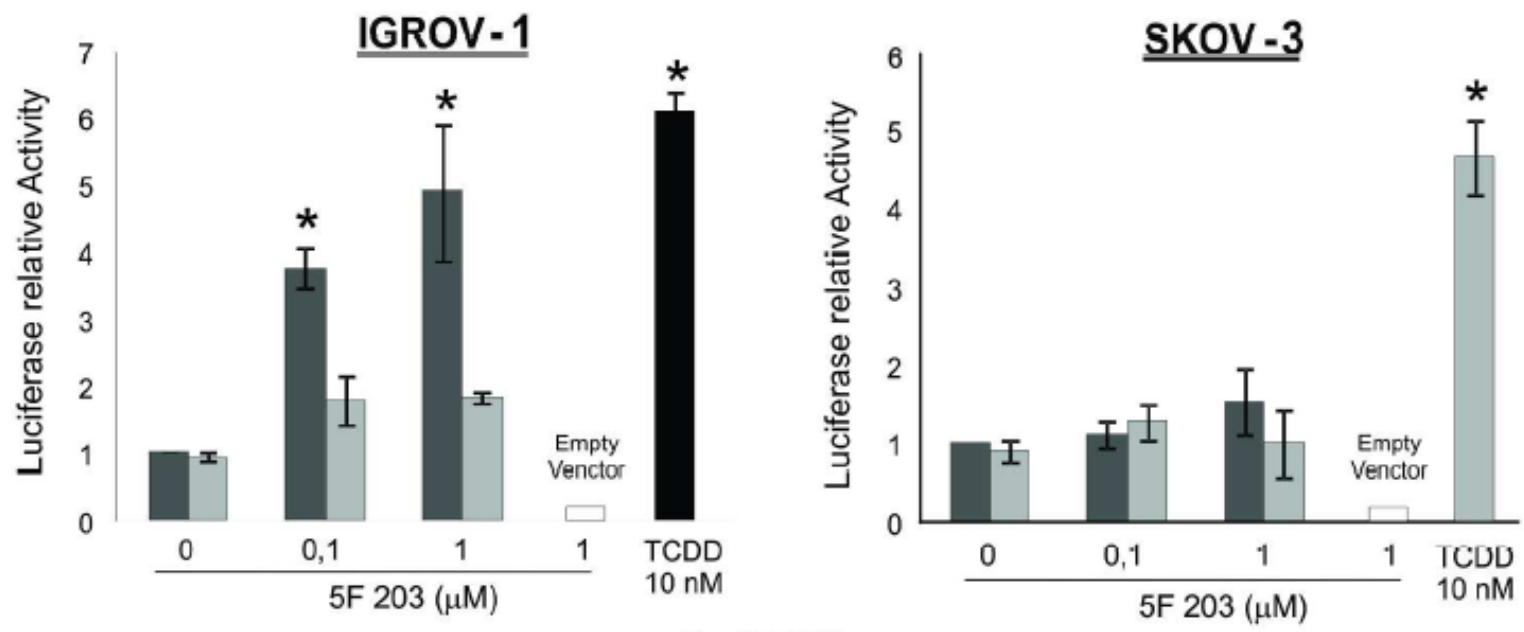

- 5F 203

¿ $\alpha \mathrm{NF}+5 \mathrm{~F} 203$

Figure 1 
A

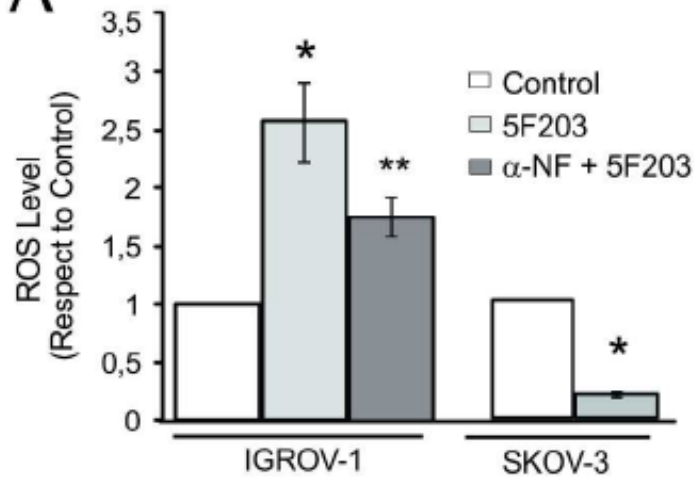

IGROV-1
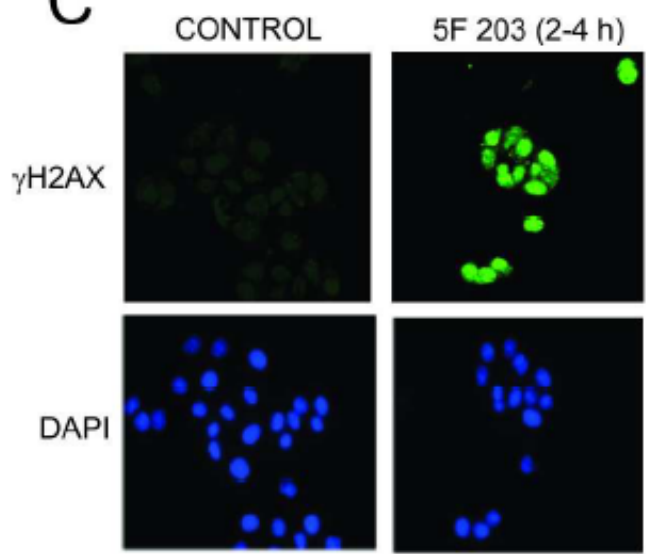

B

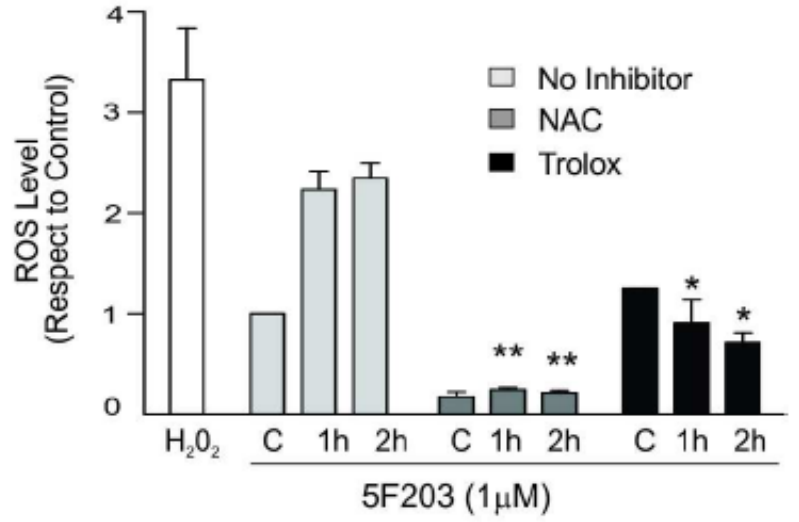

SKOV-3

$\alpha-N F+5 F 203$
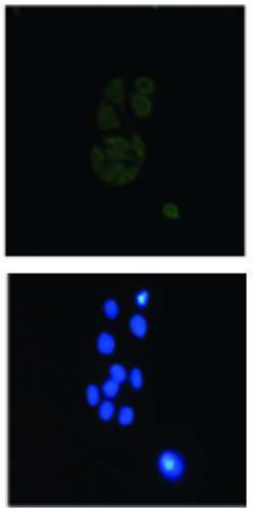

5F203 (2- 4 h)
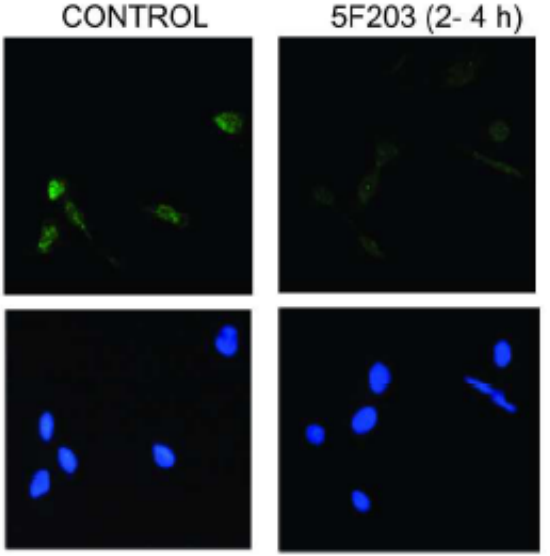

Figure 2 
IGROV-1

A

A $\quad \begin{array}{llll}\frac{5 F 203(1 \mu M)}{2} & & \alpha-N F+ \\ & \text { 1h } \quad 3 h \quad 6 h & \alpha-N F & 5 F 203\end{array}$

PERK - - - =

ERK

pJNK $---=$

JNK $-\div-\div-$

pp38

$+-$

$p 38 \alpha$

Actin

B

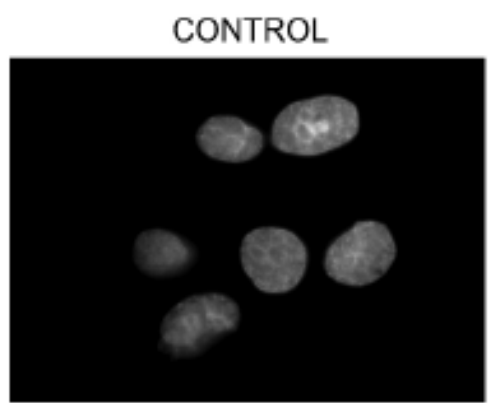

$\mathrm{NAC}+5 \mathrm{~F} 203(1 \mu \mathrm{M})$
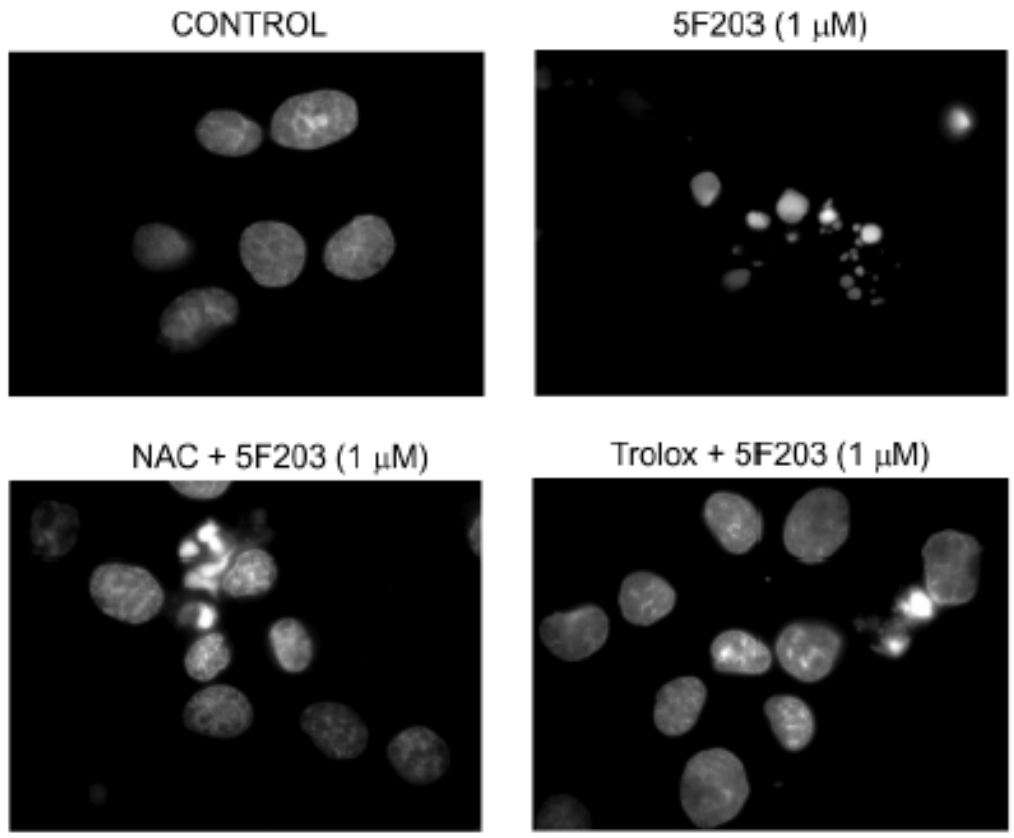

Trolox + 5F203 $(1 \mu \mathrm{M})$

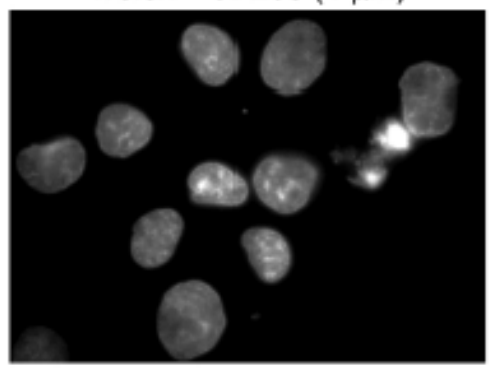

SKOV-3

CONTROL

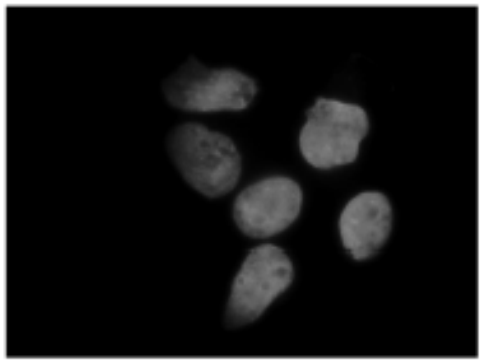

54 Kda

$38 \mathrm{KDa}$

$38 \mathrm{KDe}$

$42 \mathrm{KDa}$

IGROV-1

SKOV-3

$5 F 203(1 \mu \mathrm{M})$

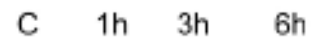

$44 \mathrm{Kda}=-\infty$

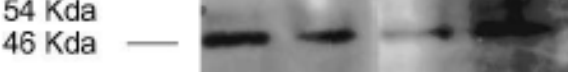

54 Kdả $-\infty-\cdots$
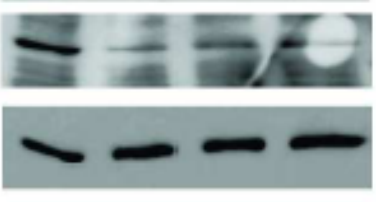

$\longrightarrow \infty$ 
A

\section{IGROV-1}

CONTROL

$5 \mathrm{~F} 203(1 \mu \mathrm{M}) 24 \mathrm{~h}$

$\underline{5 F 203(1 \mu M) 48 h}$

$-\quad \begin{array}{ll}\text { Sub-G, } & 5,23 \\ G_{1} & 44,5 \\ S & 30,28 \\ G_{2} M & 19,99 \\ \end{array}$
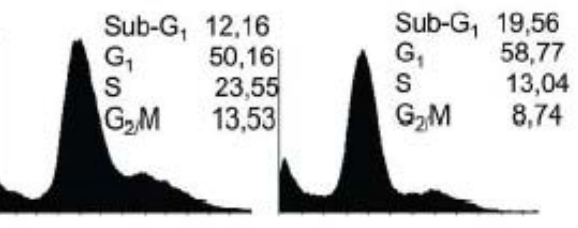

$\alpha=N F \quad \begin{array}{ll}\text { Sub-G } & 4,84 \\ \mathrm{G}_{1} & 54,53 \\ \mathrm{~S} \mathrm{M} & 23,78 \\ \mathrm{G}_{2} \mathrm{M} & 16,75\end{array}$
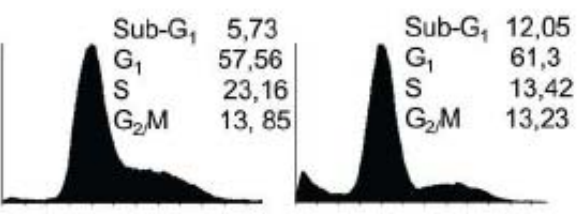

SKOV-3

CONTROL $5 \mathrm{~F} 203(1 \mu \mathrm{M}) 24 \mathrm{~h} \quad \underline{5 F 203}(1 \mu \mathrm{M}) 48 \mathrm{~h}$

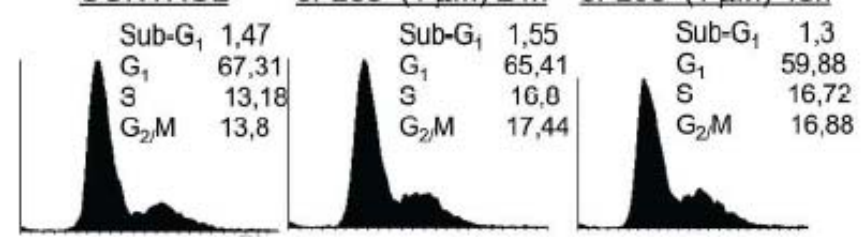

C

IGROV-1
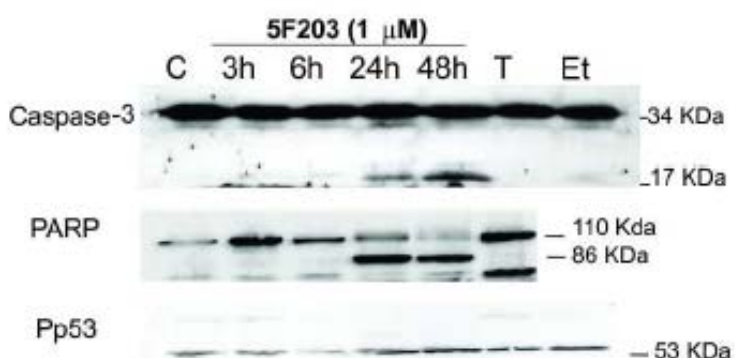

p53

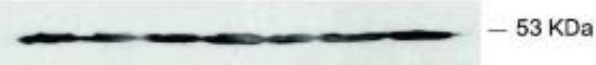

p21

Actin
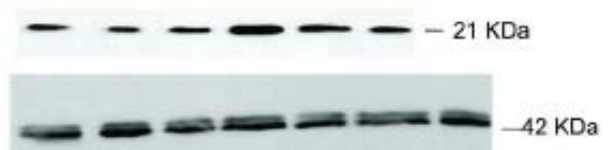

Actin
PARP

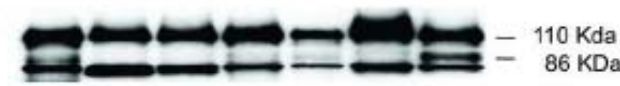

Pp53

p53
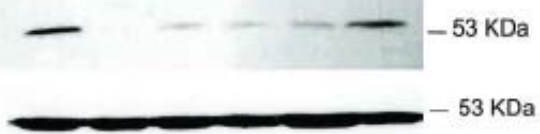

$\mathrm{Kda}$

$\mathrm{KDa}$

\section{B}

$5 \mathrm{~F} 203(1 \mu \mathrm{M})$

Cyclin D1 - - - - - $-36 \mathrm{KDa}$

Actin - - - $-42 \mathrm{KDa}$

\section{SKOV-3}

$5 \mathrm{~F} 203(1 \mu \mathrm{M})$

C $3 \mathrm{~h} 6 \mathrm{~h} 24 \mathrm{~h} 48 \mathrm{~h} T$ Et $-34 \mathrm{KDa}$

$-17 \mathrm{KDa}$

\section{Figure 4}


A

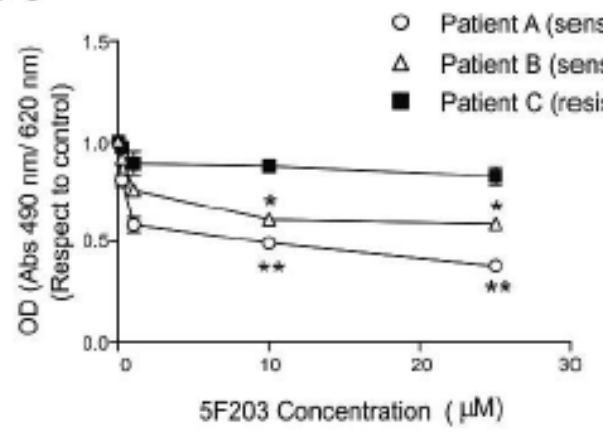

B

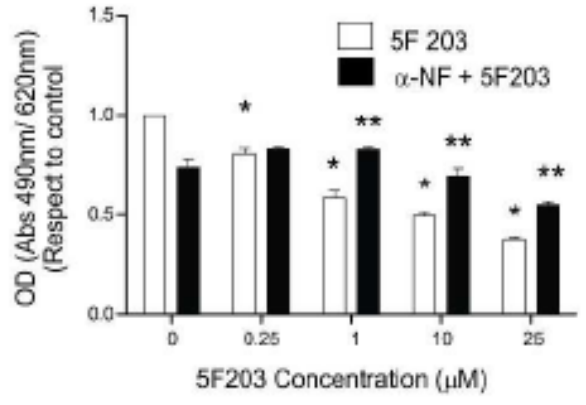

C

\section{PATIENT A}

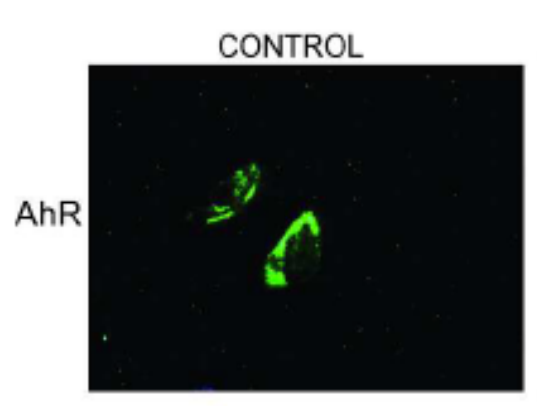

5F203 $(10 \mu \mathrm{M})$

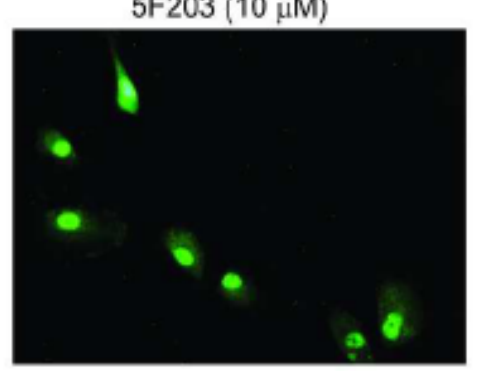

$\alpha-\mathrm{NF}+$

5F203 $(10 \mu \mathrm{M})$

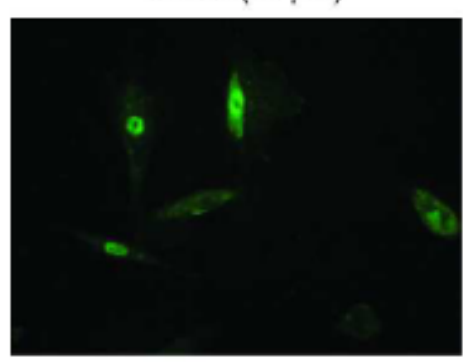

PI
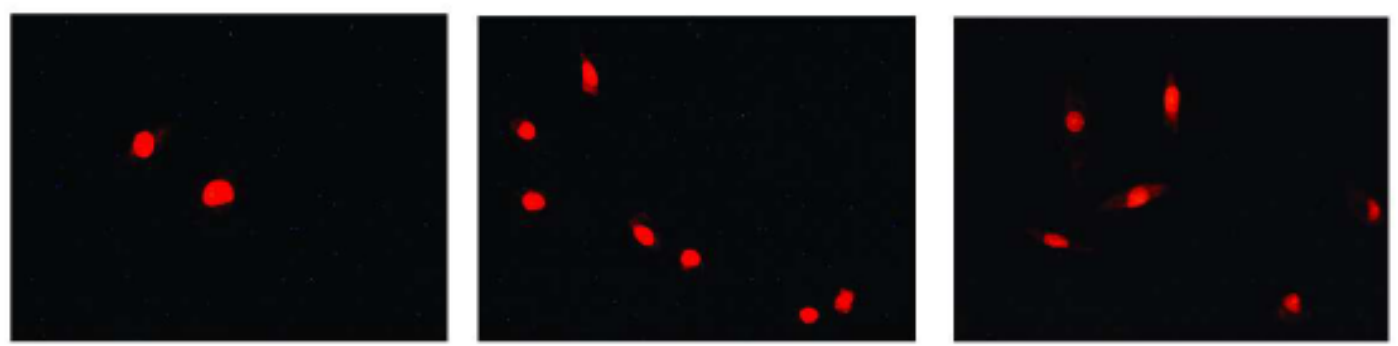

PATIENT C

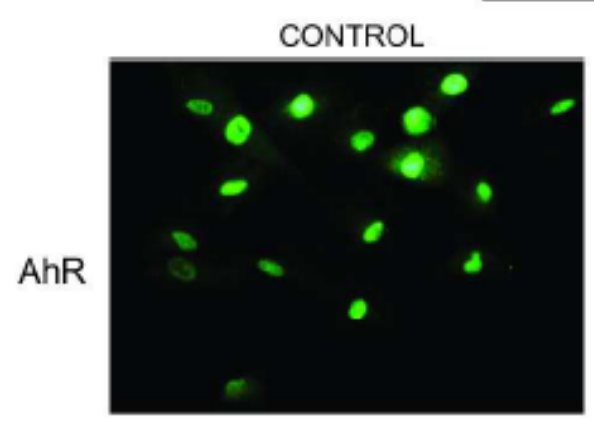

5F203 (10 $\mu \mathrm{M})$

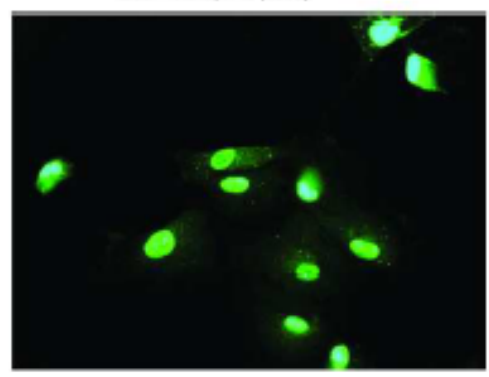

PI
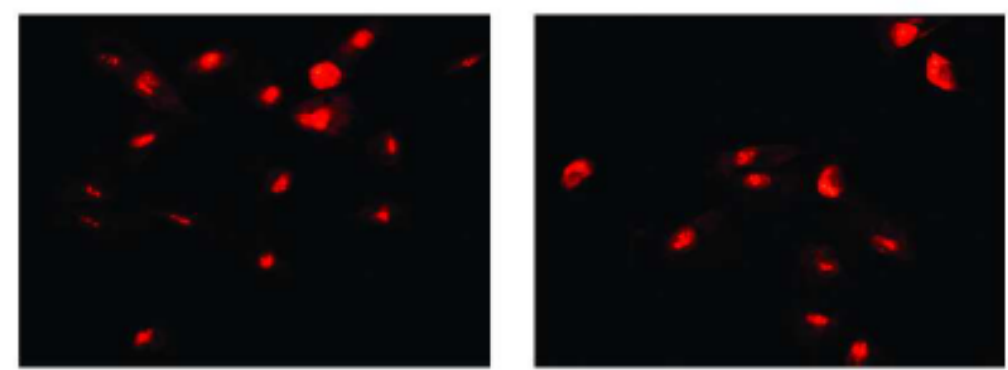

Figure 5 

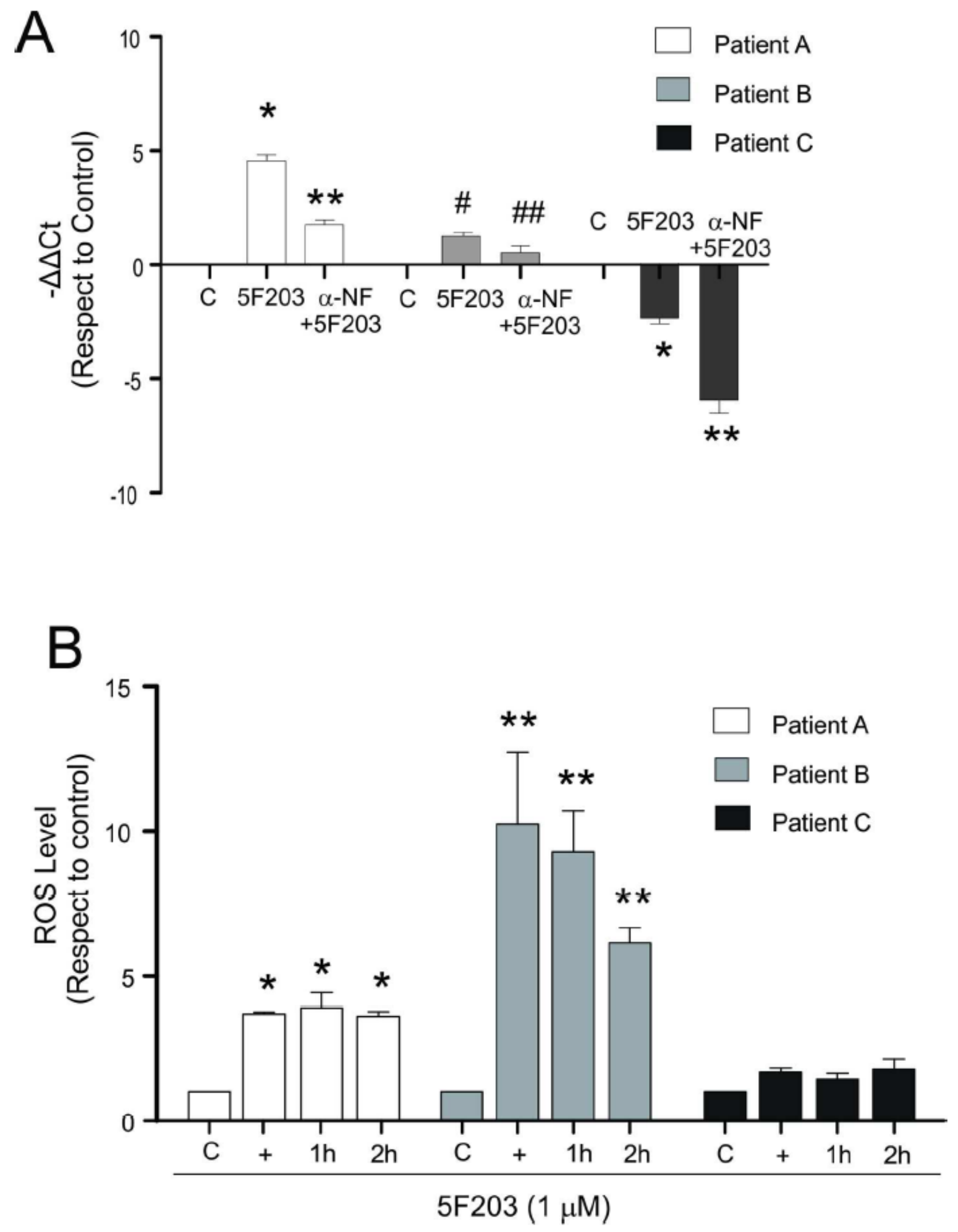

Figure 6 